\title{
The Competence and Readiness of Teachers in West Sumatra Indonesia in Implementing Curriculum 2013
}

\author{
Rino \\ Economic Education Program \\ Universitas Negeri Padang \\ Padang, Indonesia \\ rinopekon@fe.unp.ac.id
}

\author{
Armida S. \\ Economic Education Program \\ Universitas Negeri Padang \\ Padang, Indonesia \\ richard.armida@yahoo.com
}

\begin{abstract}
Curriculum 2013 requires teachers' creativity, innovation and independence. The change of paradigm required teachers to move from teacher oriented to student oriented and also to pay attention on balance achievement among cognitive, affective, and psychomotor domain. The purposes of this research are to identify competence and readiness of teachers in secondary education in implementing curriculum 2013, as well as, to find the alternative program or problem solving activities to improve the competence and readiness of teachers to implementing curriculum 2013. The method used in this research is descriptive analysis with qualitative and quantitative approach by using instruments such as document collection, observation, questionnaires and in depth interviews. Data were analyzed by using descriptive statistical analysis, document analysis, and interview analysis. The result of this research shows that teachers in secondary education in West Sumatra are competent and ready to implement the Curriculum 2013.
\end{abstract}

Keywords; Competence of Teacher, Readiness of Teacher, Curriculum 2013

\section{INTRODUCTION}

Currently, the main focus of educational quality is the quality of teachers that still far from the ideal conditions. Teachers as educators who meanwhile rated as a supporting component in education are but weak in an effort to enhance the quality Education. Data from the Ministry of Education shows that nearly half of the approximately 2.6 million teachers in Indonesia are not worth teaching. Qualifications and competence are insufficient to teach in schools. The short teachers amounted to 912.505 , consisting of 605.217 elementary school teachers, 167.643 secondary school teachers, 75.684 high school teachers and 63.961 vocational school teachers. In addition, there were $15 \%$ of teachers. Do not teach in accordance with their expertise.

Hence, a survey conducted by Putera Sampoerna Foundation in 2012 found that 54\% teachers in Indonesia still have base quality. The base quality of teachers in Indonesia acknowledged by Syawal Gultom as Chairman of the Board of Human-Resource Development and Quality Assurance of Education in Ministry of Education and Culture. According to Syawal Gultom, quoted connected by hooked up media Compass (2012), stated that in general, the quality and competence of teachers in Indonesia are still not as expected. In terms of educational qualifications, until recently (2012), from 2.92 million teachers, at most about 51 percent has the bachelor degree, while the rest did not have. The same cases happened to the requirements for his. It shows the teacher professional, just 2.06 million teachers, or about 70.5 percent of teachers are appropriate for certification. The other 861.67 teachers not fit for certification. Competence of teachers is also problematic. When a test was held for teachers, average, less than 50 percent of problems that can be solved. There is no teacher who scored 80 or above. In fact, there are teachers who earned the lowest scored.

Law number 14 year 2005 about teacher and lecture and other law which made for teachers and lecturers are solutions to the problems hindering our education, especially for teachers and lecturers as educators. This law requires three mechanisms to enhance the quality of education personnel, which are qualifications, competencies and certification. Requirements for a teacher in accordance with this law are as follows: a) having an academic qualification degree or diploma IV degree, b) having competencies in personality, social, and professional, and c) having teaching certificate. If teacher has met three of these mechanisms, then they deserve the title as a professional teacher. Thus the professional teachers according to Law No. 14 year 2005 about teachers and lecturers indicated three indicators: qualifications, competencies and certification. Professional teachers marked by the fulfillment of competencies as educators that they had. They are a professional teacher not only by certified education but also can be proved with competencies that should be possessed as a professional teacher.

This research was conducted to reveal the competence and readiness of teachers in secondary education SMA (high school), SMK (vocational school), and MA (religion school) in west Sumatra Indonesia in implementing curriculum 2013. These research objectives are; to identify the competence and readiness map of teachers in implementing curriculum 2013 in secondary education (SMA/SMK/ MA) in West Sumatra Indonesia, to identify factors that affect the competence and readiness of teachers in implementing curriculum 2013 in secondary education (SMA/SMK/MA) in West Sumatra Indonesia and, to generate alternate program or problem solving activities to improve the competence and readiness of teachers in 
implementing the curriculum 2013 in each unit of secondary education (SMA/SMK/ MA) in West Sumatra Indonesia.

Competent teachers in the perspective of Law No. 14 2005; also known as professional teachers are teachers who uphold the principles of professionalism in their profession. Law No. 14 of 2005 in article 7 mentions some of the principles of professionalism for the teaching profession, there are; have the talent interest spirit and idealism, have a commitment to improve the quality of education faith devotion and noble character, have academic quality and sufficient educational background with field of assignments, have necessary competence for the field of assignment, have responsibility to implementing the professionalism tasks, derives income determined by work performance, have the opportunity to develop the sustainable professionalism manner by lifetime learning, have legal protection and carry out the professionalism task, have qualified organizations that have the authority to regulate problems related to the duties of experienced teachers.

Competent teachers must understand and apply the values of professionalism in running their career as a teacher. If these values run with a vengeance, then of course the teaching profession will be ingrained in every teacher, and they will give total devotion as a teacher. They will consider teaching profession as an honorable profession, and run with it. If the teaching is carried on wholeheartedly and does not fully support the values of professionalism in the work, then surely they do not make the teacher as the main option in their work, so consequently they will work half and half and did not love their career. Thus, it is necessary for determination and a strong desire to be a teacher as a profession that they loved. When all the work is based in the love, it will result to a good performance on the job. Competent teachers had a number of required; knowledge, skills and behaviors, controlled internalized and professional in carrying out duties as a teacher. Following that, teacher competence is clearly written in the Law No. Teacher and lead lecture 14 of 2005 sections 10 which include personal competence, social competence, and professional competence.

Curriculum 2013 as a national strategic policy in education requires professional teachers to implement it. If the insufficient teacher as stated above is given the trust to run curriculum 2013, it is feared there will be no change in school and the world of education itself. Curriculum 2013 requires independence and professionalism of teachers to develop curriculum and learning process within the classroom.

Actually, Curriculum 2013, 2006 and 2004 has the same goal, which is the spirit of competence. But in the implementation, KBK 2004 and KTSP 2006 were not capable to support the students who have competence in accordance with national education goals that have been implemented.

From the standpoint toward the development: curriculum 1994, curriculum 2004 and 2006 as well as curriculum 2013 had different direction. Curriculum 1994 development direction aimed more at the curriculum as a document so that all learning activities more concerned about documents in material form. Materials provided very dense and serve as the main focus. So there is a proverb that develops that curriculum 1994 which CBSA spoofed 'catat buku sampai (h)abis (rewrite the book until the end)'.

From the design and mindset, curriculum 2004 and 2006 are academic subjects. This means that the central and concern are subjects that have been set so that the competencies will be formed directed from the subjects as sourced of content standards. Besides, the formations of cognitive, affective and psychomotor are done separately and make subjects as a means of forming an absolute competence in question. Thus, curriculum 2013 design and mindset was comprehensive. Its main concern is the competence comes from the analysis of needs and design of the curriculum itself.

\section{RESEARCH METHOD}

The method used in this research is descriptive. The analysis of the data was made by qualitative and qualitative approach. The data were obtained in the form of a document, the result of a closed questionnaire to the respondents and the result of an open questionnaire to the respondents where explanation described clearly and systematically so data are presented comprehensively and easily to understand. This research consisted of three phases of activity; the stage of mapping competence and readiness of teachers to implementing curriculum 2013, the stage of identifying the factors causing differences in competence and readiness of teachers to implementing curriculum 2013 and, the stage of developing a model of alternative solutions to increase the competence and readiness of teachers to implementing curriculum 2013.

The location of this research were SMA (high school)/ SMK (vocational school)/MA (religion school) in West Sumatra Indonesia. The populations in this research were all teachers of SMA (high school)/ SMK (vocational school)/MA (religion school) in West Sumatra Indonesia. To obtain data related to the purpose of this research, researcher used questionnaires, interviews and documentation. Data obtained from the distribution of questionnaire were analyzed by using descriptive statistic to view the presentation of the answers. Data obtained from interviews with teachers were analyzed using justification theory in order to obtain a relatively steady answer.

Respondents of this research were all high school (SMA) teachers, vocational school (SMK) teachers and religion school (MA) teachers in West Sumatra. Based on BPS data recorded in 2014, the number of high school teachers, vocational and MA teachers in West Sumatra are 23.934, spread in 1.325 high schools, vocational school and MA in both public and private school. After used proportional stratified random sampling technique, the obtained sample as follows: in phase I (first) sampling counties and cities, from 19 counties and cities selected 5 districts namely Padang Pariaman, Pariaman, Bukittinggi, Agam and Tanah Datar, In stage II (second) sampling drawn to determine the sample size by using Herry King tables, in order to obtain a sample size as many as 344 teachers. Then, researcher subsequently determined the proportion of each selected districts about how many samples to be selected. Bukittinggi with 73 questionnaire (38 high school, 26 vocational and $6 \mathrm{MA}$ ), Pariaman with 44 questionnaire (19 high school, 22 vocational and 3 MA), Agam with 102 ques- 
tionnaires (47 high school, 27 vocational and 28 MA), Padang Pariaman with 70 questionnaires (51 high school, 13 vocational and $6 \mathrm{MA}$ ), and Tanah Datar with 56 questionnaires (17 high school, vocational 19 and $19 \mathrm{MA})$.

\section{RESULT AND DISCUSSION}

A. The Competency Mapping of SMA (High School), SMK (vocational school), and MA (religion school) Teachers

Based on research data that had been collected from high school teachers, MA and vocational school teachers about competency mapping of teachers in West Sumatra, it concluded that out of the four competencies that should and must be owned by teachers; pedagogic competence, personal competence, social competence and professional competence, this research found that pedagogic and professional competence are below the average score. It means that teachers' pedagogic and professional competence is in trouble and need systematic, planned and continuing efforts to fix this problem.

This research findings reinforce and consistent with the national test standard for teacher and national instructor training organized by Ministry of National Education that performs a number of competency test for teachers and training of national instructors for knowledge on all subjects which found that teachers have problems on their ability in terms of mastery the subject material. Thus, the ability of teachers on the pedagogical and professional should be given attention by government in an effort to improve the quality of teachers in Indonesia. But that is an important finding in this research that the results of the national test standard for teacher and training of national instructors for national curriculum 2013 did not describe in detail; the abilities of teachers is problematic so it is not known for certain terms of professionalism and the pedagogical problem that needs to be improved in improvement program. Research findings provide clear picture in mapping competencies so that two troubled competence has been identified of each competency that became problematic, the causes and alternative forms of problem solving and program / activities that can be done to solve the problem.

\section{B. The Readiness Mapping of SMA (high school), SMK (vocational school), MA (religion school Teachers in implementing Curriculum 2013}

Based on data collected through questionnaires and have been proceed, this research found that out of the four standard curriculum 2013; graduation standards, content, processes and assessment, that the readiness of teachers in West Sumatra Indonesia to implementing graduation standards and process are problematic, so the teacher is not ready to implement these two standards, compared with the other two standards. High school teacher is not ready in terms of graduation standards, content and processes, religion school teachers are not ready in terms of graduation standards, assessment and process, and vocational school teachers are not ready in terms of graduation standards and the standards process. The findings of this research would provide important information for various parties, both school and Minister of Education and Culture in
West Sumatra, where the teachers not showed good preparedness to implementing curriculum 2013, especially in terms of graduation standards and the standards process. Logically teachers judged competent and had passed the certification course said to have the readiness to implementing curriculum 2013. Because of the training that has been done during this national education department to prepare teachers to implement NATIONAL CURRICULUM 2013 has taken substantial funds. However the facts in the field indicate it is not maximized. The findings of this research at least consistent with research performed by Balitbang Team, Medan, Susanti and Isnaini, Brotosedjati, Wahyudi and Suji, Murwati, Hurmaini which concluded that teacher certification programs in order to improve performance and quality of teachers have no significant effect on the performance of teachers. Hence, this research found that the training of curriculum 2013 done by the national education department does not affect positively to improve the performance of teachers who in turn also has no effect on the readiness of the teachers to implement the curriculum 2013. Therefore NATIONAL CURRICULUM 2013 training activities that have been done so far needs to be evaluated related to its sources, materials, methods of training and evaluation and monitoring process so that problems unpreparedness of teachers in implementing NATIONAL CURRICULUM 2013 can be resolved completely.

\section{Factors Affecting Teachers' ${ }^{6}$ Competence and Readi-} ness to Implementing Curriculum 2013 in Secondary Education Units SMA (high school), SMK (vocational school), MA (religion school)

This research found factors affecting the competence and readiness of teachers in implementing curriculum 2013. Factors that affect the competence of teachers are: experience, motivation, intellectual ability, levels of education, openness to innovations, local cultures, evaluation, supervision, and emotional.

This research also found the factors that affect the readiness of teachers to implement curriculum 2013, they are: beliefs and values, skills, experience, personal characteristic, motivation, intellectual ability, organizational culture, levels of education, openness to innovations, responsibility, local cultures, skills, financial, evaluation, supervision, awards, attention to welfare, and emotional factor.

These factors correspond to what was raised by some experts in the field of human resource management; among others Micheal Zwell said that the employee performance in the sense of competence includes the ability of a good working knowledge, attitudes and skills influenced by several factors including; beliefs and values, skills, experience, characteristics of personality, motivation, emotional issues, intellectual ability, and organizational culture.

It is supported by the concept of performance proposed by Wirawan which identified several factors that affect employee performance and organizational performance; First, the external environment consists of the economic, political, social, cultural, religious, community and competition. Second, internal factors consist of employee talent and personal qualities, 
creativity, knowledge and skills, competencies, work experience, physical and psychological condition. Third, the organization's internal environment consists of the vision, mission, organizational goals, organizational policies, raw materials, technology, organizational structure, management system, compensation, leadership, capital, organizational culture, organizational climate and coworkers. Fourth, the behavior of the employee consists of ethical work, work discipline, work motivation, morale, job stress, job involvement, leadership, job satisfaction and loyalty. These four factors of internal environments, the external environment, and factors above affect the achievement of the performance of employees could affect organizational performance.

\section{How The Alternative Programs/Activities Seen as a Solution to Increase The Competence and Readiness of Teachers to Implementing Curriculum 2013}

Based on the results of data processing and analysis, it can be concluded that competence and readiness of teachers to implement the curriculum 2013, the causes and solutions to solve, then the program or activity that can be done to improve teacher competence: held teacher community learning intensively, training of achievement motivation for teachers, innovative and creativity competition for teachers, information and technology training, collaboration of action research among fellow teachers and lecturers in universities, training for development potential of students, and, management training for teacher professionalism.

Meanwhile, to improve the preparedness of teachers to implementing curriculum 2013, mainly in four standards: graduation standards, content standards, standardized processes and standard of assessment, can be done; training, supervision concept and implementation of national curriculum 2013, training guidance and development of hard and soft skills of students, supervision and development of teaching materials based on the content locally, nationally and internationally for teachers of science, social studies and mathematics, information and technology training.

Various forms of program or activity that was create based on map of problems and the causes should be done with full and sustainable efforts needed to monitoring mechanism so that the results can be seen regularly. Programs or activities that create in accordance with the policy of academic manuscript of teacher educational program in 2012 by the National Human Resource Development and Education Culture and Education Quality Assurance of Ministry of Education and Culture in 2012 developed a program called PKB that sustainable performance improvement. Two forms of activities carried out in this agreement consist of training and non-training activities. Several form of training activities are in-house training through held teacher community learning intensively, internship program, a partnership of school, distance learning, tiered training and specialized training, an internal coaching by the school, further studies.

While some forms of non-training activities are: discuss issues of education, seminars, workshops, research, the writing of books/materials, the manufacture of media, and, the making technology work/art.

Hence, this research also explained that some kind of program/activities that can be done in the PKB activity consists of three main activities; activities that teachers do by themselves, the activities performed by the teacher with each other, and the activities conducted by the school. Activities conducted by the teachers themselves consist of: analyzing the feedback obtained from students towards studies, analyzing the learning outcomes (test scores, student skills, etc.), observing and analyzing student responses to learning activities, reading articles and books related to the fields and professions; and, taking courses or distance training.

Activities conducted by teachers in collaboration with other teachers are; observeing other teachers, inviteing other teachers to observe teachers while they teaching, teaching together with other teachers (patterns of team teaching), in conjunction with other teachers to discuss and investigate the problems faced in school, discussing articles or books with other teachers, and designing to make teaching preparation together with other teachers

While the activities that can be done by the school are: conducting a training day for all human resources in the school (not just teachers), visiting the other schools, and, inviteing persons/speaker from other schools or from other agencies.

\section{CONCLUSION}

The competence mapping of teachers in West Sumatra made from four competencies that must be owned by teachers; pedagogic competence, personal competence, social competence and professional competence, found that two competence are problematic because under the average score (pedagogical and professional competence). While the map of readiness of teachers to implementing curriculum 2013 showed that from the four standards of curriculums 2013; graduation standards, content standards, standardized processes and standard of assessment found that the readiness of teachers in West Sumatra in implementing graduation standards and the standards process are problematic. It means that the teacher is not ready to implement these two standards compared to the other two standards.

This research found a number of factors affecting the competence and readiness of teachers to implementing curriculum 2013. Factors affect the competence of teachers are skill factors: experience, motivation, intellectual ability, levels of education, openness to innovations, local cultures, evaluation, supervision, and emotional.

This research also found number of factors that affect the readiness of teachers to implementing curriculum 2013, namely; beliefs and values, skills, the experience, characteristic, motivation, intellectual ability, organizational culture, education level, openness to innovations, responsibility, local cultures, skills, financial, evaluation, supervision, awards / attention to welfare, and emotional.

Based on the map of competence and readiness of teachers to implementing curriculum 2013, the causes and solutions to 
solve, then the program or activity that can be done to improve teacher competence are; teacher community learning intensively, training of achievement motivation for teachers, innovative and creativity competition for teachers, information technology training, collaboration of action research among fellow teachers and lecturers in universities, training for potential development of students, management training for teacher professionalism.

Meanwhile, to improve the preparedness of teachers to implementing curriculum 2013on four standards; graduation standards, content standards, standardized processes and standard of assessment can be done; training, supervision and supervision concept and implementation of national curriculum 2013, training guidance and development of hard and soft skills of students, supervision and development of teaching materials based on the content locally, nationally and internationally for teachers of science, social studies and mathematics, information technology Training

\section{REFERENCES}

[1] Ministry of National Education. 2006. The Visions of our Education: an Anthology of Articles from 2005 to 2006. Jakarta: Ministry of National Education Center for Information and Public Relations.

[2] Putera Sampoerna Foundation. 2012. 54 percent of the quality of teachers is still low. (Online). Regarding Indonesia.com, accessed 21 September 2013 .

[3] Gulton, Syawal. 2014. Teacher Quality Still Low. (online). http://edukasi.kompas.com/read /2012/03/07/08304834/Quality.Guru.Masih.Rendah.20Rabu20720Maret. 202012, accessed March 2, 2014.

[4] Law No. 14 of 2005 on Teachers and Lecturers

[5] Ministry of Education and Culture. 2013. Basic Framework and Curriculum Structure 2013. Kemendikbud. Jakarta.

[6] Ministerial Regulation No. 18 Year 2007 on Certification for Teachers

[7] Government Regulation No. 19 of 2005 on National Education Standards

[8] Government Regulation No. 19 of 2005 on National Education Standards

[9] Ministry of Education and Culture. 2013. Basic Framework and Curriculum Structure 2013. Kemendikbud. Jakarta.

[10] Balitbangda Medan. 2011. Provision of Professional Allowance and Its Effect On Teacher Performance In Elementary, Junior High, High School, Vocational School In The City Of Medan. Medan: Research and Development Agency.

[11] Susanti, Isnanini. 2012. PLPG Influence on Performance of Certified Social Science Teachers in Junior High School in Jember. Scientific

[12] Brotosedjati, Soebagyo. 2012. Performance of Teachers Whose Passed The Certification. JMP, Volume 1 Number 2, August 2012. 189-199.

[13] Wahyudi, Suji. 2012. Measuring Performance of Teacher Certification Program. International Journal of Administrative Science \& Organization, September 2012. Volume 19, Number 3. 155-161

[14] Murwati. 2013. The Influence of Teachers Professional Certification on Work Motivation and Performance in SMK in Surakarta. Journal of Business and Economic Education (BISE) Vol.1 No. 1 Year 2013.12-21.

[15] Hurmanini M. 2011. Impact of Teacher Certification Implementation on Improvement of Teacher Performance in the Learning Process: Study of MTs Negeri Jambi. Media Akademica Vol. 26 No. 4. 2011. 500-535.

[16] Wibowo, Tjiptono. 2002. Competency-based Education. Yogyakarta: Atma Jaya University.

[17] Wirawan. 2009. Performance Evaluation of Human Resources: Theory, Applications, and Research. Jakarta: Salemba Empat. 